\title{
Interfaith Relations within the Emerging Field of World Christianity
}

\author{
S. Wesley Ariarajah
}

\section{Introduction}

“The interdisciplinary area, 'world Christianity,' investigates the histories, practices, and discourses of Christianity on six continents. It examines local forms of Christianity as well as global interconnections that make Christianity a world religion," says the introduction to The Journal of World Christianity (2017.1). It states further that "As a field of study, world Christianity emerged historically from mission studies, ecumenical theology, and the academic study of world religions," and adds that "While it is not reducible to any of these three, they each continue to play an important role in informing its work."

I begin this chapter with this definition of World Christianity, which is helpful, but still needs further refinement, because it is no secret that the phrase 'World Christianity' has been understood in many ways; there has been a gradual evolution in the understanding of what the phrase actually meant and what needs to be included in it. Some uncertainty continues to persist as to what areas of study should feed into this emerging field. There is a good reason for this uncertainty. Although the academic world is aware that Christianity today is a global phenomenon, centuries of association makes it difficult to disassociate the Western Hemisphere, Christian theology that emerged within it, and its cultural ethos from what is considered 'Christian' and Christianity.

When churches in Asia, Africa and Latin America began, at the end of the colonial era, to do a new phase of theological work of their own, which included challenging the theological tradition received from the Western theological heritage, there was considerable wavering on their part on how to relate their work to the received Western theology. There was also ambiguity on the part of theological educators, both in the East and West, on how to incorporate the new theological impulses into the theological curricula in the seminaries. This uncertainty is reflected even today in the way many seminaries organize their courses on theology.

Most seminaries have a required course or 'Christian Theology' or 'Systematic Theology', where the classical theology of the Western tradition is taught. The 
new awareness that Christianity is no longer and never was only a Western phenomenon is responded to by the offering of other, elective courses on 'Third World Theologies', 'Asian Theologies', 'African Christologies', 'Liberation Theologies' and so on. This simple fact shows how far we need to go before the word 'Christian' assumes the dimensions it needs to assume in today's world.

The initial interest in looking at Christianity as a global phenomenon to be reckoned with arose within missiology. Over the decades the influence of Christianity and church membership began to fall within the Western world, especially in a number of European countries, while many forms of Christian missions recorded increasing numbers in other parts of the world, especially in Africa and some parts of Asia. This reality led to the sentiment that the 'centre of gravity of Christianity' has moved, or in the process of 'moving to the South', drawing particular attention to the growth of Christianity in the nonWestern parts of the world. Although serious ambiguities plague the nature of the growth of Christianity in these parts of the world, especially on the kind of gospel message that is promoted, the apparent success of the 18th and 19th century types of missions in the 21st century was sufficient to arouse an interest in a new field of study under the rubric of 'World Christianity'. Although Christianity was an unacknowledged global reality long before these developments, the assumed 'moving of the centre of gravity to the South', supported by statistics and maps within the mission constituency, was mostly instrumental in bringing this field to the forefront (Gallagher 2009; Tan and Tran 2016).

However, once the concept of 'World Christianity' caught on, the other fields of study have also begun to pay attention to the great variety of theological, spiritual, prophetic, and socio-economic dimensions of Christian faith and forms of Christian discipleship that is manifest in the non-Western world (Tennent 2007; Tan and Tran 2016). ${ }^{1}$ Although the seminaries both in the North and South still treat the classical Western theological tradition as the 'Christian' tradition, there is sufficient awareness of its limitations and of the need to prop up the course on Christian Theology with additional courses. It may take several decades before meaningful changes would begin to appear in this area, where the study of Christian Theology would take full account of the diverse and multifaceted nature of the Christian theological reflections in the world.

Much more can and needs to be said in this area, but let me turn to the subject of this contribution, which is on the place and role of interfaith relations within the emerging field of World Christianity.

1 The volume edited by Jonathan Y. Tan and Anh Q. Tran (Orbis 2016) carries analyses by twenty leading scholars on the implications of the demographic changes and growth of Christianity to the understanding of Christian faith. 


\section{Some General Characteristics of Christianity in the} Non-Western World

Although the growth and spread of Christianity in the Western world was gradual, subjected to the vicissitudes of historical events, the rise and fall of empires, and the emergence of Islam, by the time organized 'world missions' were directed to Asia and Africa, Christianity had become the dominant religion of Europe and North America. Four characteristics need to be taken into account in understanding the missionary movement's encounter with the non-Western world, especially in the 18th and 19th centuries:

- Many of the countries to which the Christian message was taken were under colonial rule. The power imbalance that this reality created made a significant impact on the nature of the mission directed to the peoples of Asia and Africa.

- The Western world had emerged out of the Middle Ages and had undergone many revolutions: Renaissance, Enlightenment, Reformation, Scientific Revolution, and so on. This led the Western world to develop an uncritical belief in the superiority of the Western culture over all other cultures.

- Having not yet integrated the benefits of the Industrial Revolution, much of the non-Western world was in comparative poverty, and had entrenched traditional social structures that discriminated against large sections of its people, which opened up significant points of contact for missionary work. Commenting on this reality, David J. Bosch says: "The Enlightenment ... together with the scientific and technological advances that followed in its wake put the West at an unparalleled advantage over the rest of the world. Suddenly a limited number of nations had at their disposal 'tools' and know-how vastly superior to those of others. The West could thus establish itself as master of all others in virtually every field. It was only logical that this feeling of superiority would also rub off on the 'religion of the West', Christianity." (Bosch 1996: 291)

- Most of the counties had strong and vibrant religious traditions that had lasted for centuries and had shaped the faith, culture and ways of life of its people. But the philosophical and religious/mythical dimensions of the socalled 'Asian religions' made little sense at that time to those who brought the Christian message to these countries.

To these observations one should add an additional fifth reality, relevant to our current discussion: Despite the centuries of contact with Christianity, and the Christian attempts to displace other religions and plant itself as the dominant religion, as it did in Europe and South America, the Asian religious traditions persist; Christianity in almost all Asian countries (with the exception of the Philippines and East Timor) remains a minority religion. 
In-depth study of the nature of these realities and how the Western theological traditions and missions dealt with each of these aspects, the nature of the Christian communities they created, their present situation, and the relationship they maintain with the rest of the Christian world are areas that are being explored today within the field of World Christianity. However, since religions play a central role in shaping the life of the peoples of Asia and Africa, it is important to have a closer look at the place of interfaith relations in the study of World Christianity. Although much can be said on the way these realities played out in Africa, I would limit this presentation to South Asia, with which I am more familiar.

Speaking about the major role other religions has played and continues to play on the Christian reality in Asia, Felix Wilfred says:

Asian Christianity presents many new prospects and hope for global Christianity, especially through its encounter with the ancient religious traditions of the continent, Buddhism, Hinduism, and Daoism. The development of Asian theology in the last few decades has demonstrated that it has the potential to open up new horizons and vistas for global theological thinking.

Wilfred 2014a: 2

Pointing out that the interaction between Christianity and other faith traditions is only at its beginnings, he holds that not only the impact of other religious traditions on Christianity but also the impact of Christianity on Asian religions and social realities of Asia should be matters of study in World Christianity:

The impact of Christianity in Asia cannot be overestimated: it led to intellectual revolutions, religious-cultural confrontations, and social conflicts but also to fundamental transformations of Asian societies. In the process, Christianity has also been transformed, leaving us not only with a rich legacy of theological controversies but also substantial contributions which are of importance for Christianity worldwide.

Wilfred 2014a: 2

Having said this, Wilfred agrees with the observation with which I have begun this essay that "Although the importance of Asian Christianity is being recognized, with the exception of a few general statistical compilations and missionary encyclopedias that often suffer from confessional bias, there are still relatively few scholarly studies available that can claim to cover the whole region and serve interested scholars in other disciplines." (Wilfred 2014a: 3 ) 
From the observations above it is clear that there are two major areas of exploration that can be usefully pursued within the field of World Christianity as it relates to Christian engagement with the religious traditions and cultures of Asia: The first is how the reality of other religions in Asia has impacted the arrival and the continued presence of Christianity in Asia. And the second, how the arrival and presence of Christianity impacted and continues to impact the religious, cultural, and social realities of Asia. Studies on the impact of the Asian religious traditions on Christianity need to begin with the recognition that there are four significant phases in Christian encounter with Asian religions. These are the 'early encounters' before the missionary era, the encounters with Christianity brought by the Roman Catholic and Protestant Missions during the colonial era, the post-colonial interactions between the churches and other religions, and the current adversarial encounters as the result of evangelical movements that come into Asia, supported by financial resources from other parts of the world. In this discussion I would deal mainly with the first two phases.

\section{The Impact of Asian Religions and Cultures on Christianity}

\section{1}

\section{The Early Encounters}

It is far too common to associate Christian presence in Asia with the missionary expansion during the colonial era when Roman Catholic and Protestant missions began to plant Christian communities on Asian soil. In reality, there is a fascinating relationship between Christianity and Asia from the very early stages of Christian history. It is difficult to determine when exactly Christianity first came from what was considered West Asia (the Middle East today) to the other parts of Asia. But it is known that already during Jesus' time there were trade routes via sea connecting the Middle East to India and beyond. There was also a land route leading all the way to the provinces of China, later to be called the 'Silk Road'. These trade routes had led to the establishment of Arab, Jewish, Persian, and Armenian settlements in different parts of Asia (Moffett 1998).

What is of significance is that these trade relations had resulted in the presence of Syrian, Nestorian, Armenian and Chaldean Christian communities in Asia. There is evidence to suggest that Christians lived in this very early period of Christian history in several Asian countries, including China, Tibet, India, Sri Lanka, Myanmar, Java in Indonesia, and perhaps in Korea and Japan via China (Moffett 1998; Moffett 2005). It is unfortunate that we have very little information on most these communities except on the Nestorians in China and on the Syrians, who reached the Western coast of India known as Malabar, which is 
today called Kerala. Happily, the Syrian tradition that struck roots in Kerala is a vibrant community today, with a strong oral tradition that the Apostle Thomas himself came with the gospel message to Malabar in 52 C.E, established a number of churches and was martyred in the latter part of his life. Although the historicity of St. Thomas' visit is difficult to prove, there has been a Christian community called "St. Thomas Christians" in the western coast of India at least from about 200 C.E. (for details see England 1996).

Evidence suggests that both the Nestorians and Syrians who brought Christianity to China and India had developed cordial relationship with the rulers, the peoples, and their religious traditions. St. Thomas Christians' accommodation to the religion and culture of the Hindus was such that they were considered "Hindu in culture, Christians in religion, and Oriental in worship" (Podipara 1973: 107-112). Although studies exist on the early Christian movement towards Asia and of the two specific traditions mentioned above, the content of the Christian message taken to these Asian countries, the nature of the Christian communities that were established, and the kind of the interaction between Christianity and the religions of that period should be of intense interest to the field of World Christianity (Rae 2012; Winkler 2013). Apart from the very early movement of the Christian faith into the Diaspora Jewish communities of Asia Minor and to the Gentiles who surrounded them, these early movements into Asia were, in fact, the first faltering infant steps of the early Christianity's eventual emergence into 'World Christianity'.

\subsection{Encounter with the Missionary Movement}

The second period of Christian relationship to Asian religions relates to the Roman Catholic and Protestant Missions that came into Asia along with the colonial powers. We shall see the impact of Christianity on Asian religions at a later stage. First we need to consider the impact of the Asian religions on Christianity and on those who brought the Christian message into Asia (Ariarajah 1991). ${ }^{2}$ Some of the missionaries who had come with the hope of bringing 'the light of the gospel message' to those who lived in 'ignorance and darkness' underwent spiritual and theological transformations by their encounter, for instance, with Hinduism. ${ }^{3}$ They were awakened to the reality that these religious traditions were not superstitions or paganisms, as they had

2 I have done a detailed study of this question in my volume, Hindus and Christians. A Century of Protestant Ecumenical Thought. Amsterdam: Rodopi and Grand Rapids, MI: William B. Eerdmans, 1991.

3 The familiar examples are those of Roberto de Nobili in India and Matteo Ricci in China who entered into dialogue and conversation with the religious traditions of the land that challenged and changed their theology and spiritual practices. 
been led to believe, but genuine spiritual traditions that gave spiritual vitality to their adherents. As a result the missionaries had to re-examine the assumptions and presuppositions about other religious traditions that were behind the missionary enterprise and of the missionary message and methods.

One of the useful resources I have used to study this are the materials related to the first World Missionary Conference, called under the leadership of John R. Mott, in Edinburgh, Scotland, in 1910. Mott's intention was to bring together all the Western missionary societies and mission agencies, to pool the missionary resources and to develop common strategies by which the rest of the world would be evangelized during that generation, even as Europe and Latin America were evangelized earlier (Ariarajah 1991: 17ff). Much has been said and written about this first World Missionary Conference, especially during its Centenary celebration in 2010 (Stanley 2009). Although I have recalled this discussion in my earlier writings, it is important to re-visit one of the aspects of this conference in order to have an understanding of the nature of the impact Hinduism, for instance, had on missionaries who had come with the vocation to preach the Christian message to the Hindus.

\subsection{Work of Commission IV of the World Missionary Conference}

The Edinburgh Conference (from 15-23 June, 1910) carried out its work through a number of Commissions, and the title of Commission I, "Carrying the Gospel to all the non-Christian World," which constituted a survey of the "progress of evangelization" and the areas "yet to be occupied", indicates the primary focus of the Conference. Among the other topics related to mission work, Commission IV was asked to reflect and report on the "Missionary message in relation to non-Christian religions."

In preparing for its work, Commission IV followed a methodology that would make all the difference to its work. In order not make its work purely theoretical, the Commission decided to call upon missionaries working in the mission fields to share their experiences and thoughts on the missionary message in relation to other religions. A questionnaire was prepared, asking questions on what should be the attitude and approach of the missionaries to other religions, the points of contact for the presentation of the Christian message, what aspects of Christianity appealed to non-Christians and what aspects of the Christian message were a hindrance to its reception. My intention here is not to recount the work of the Commission, but to reflect briefly on a few of the sixty-one responses that the commission received that made significant impact on its work and report.

The respondents said that Christians should have a "sympathetic attitude" towards Hinduism, "based on prolonged and patient study, so that such 
sympathy may be based on knowledge and not be the child of emotion or imagination" (Report Commission IV: 171). A respondent from Calcutta asked: "Is it not a reasonable demand to any man who tries to tackle so difficult a problem as that of changing other men's faith that he should know what he is talking about, not only his own religion, but also that which he desires to lead the people away from?" (Report Commission IV: 171).

S.W. Stanthal claimed that Christian knowledge of Hinduism should go beyond familiarity with its history, ritual, and philosophy, to the point of grasping, as far as one is able, the 'real life' that throbs within:

Below the strange forms and hardly intelligible language lies life, the spiritual life of human souls, needing God, seeking God, laying hold of God so far as they have found Him. Until we have at least reached so far that under the ceremonies and doctrines we have found the religious life of the people, and at least to some extent have begun to understand this life, we do not know what Hinduism really is, and missing the essential connection with peoples' religious life.

Report Commission IV: 172

Another missionary to India, Bernard Lucas, is typical of the overall attitude taken by a number of respondents:

In answer to your question as to points of contact between Christianity and Hinduism I should put first and foremost the spiritual view of life as opposed to the materialistic conception of the West. Though the quality of this spiritual view may be very deficient, and though it may contain much which is erroneous, yet there can be no question that in Hinduism, religion is, and has always been, the supreme concern of the Hindu mind. The belief that the things that are seen are temporal, while the things which are not seen are eternal, is deeply ingrained in the Hindu temperament.

Commission on the Missionary Message, 92-107

The intention here is not to give a full account of the responses received and the Report of Commission IV, which challenged the missionary assumptions about other religions, but to point out that the Christian encounter with other religions made significant impact of Christianity itself and its missionary enterprise. The unpublished bound volumes of responses from those missionaries who worked not only in the Hindu context but in the context of many of the religious traditions of Asia and elsewhere are a treasure trove hidden away in the wCc library shelves and the archive (Cracknell 1995). 
The field of World Christianity needs to do studies on this dimension because it is very often forgotten that it is the missionaries themselves, based on their lived experiences, called for radical changes of the missionary assumptions. It was the missionaries, who had been sent into situations to preach the gospel, that began to speak back to their mission agencies against racism, against the destruction of the cultures and ways of life of the first peoples of North and South America, against crushing poverty of the masses, and against the dictatorships that subjugated peoples, often with the knowledge and support of the nations that had sent the missionaries. This is a field within 'World Christianity' that awaits fuller exploration.

\section{4 \\ The Impact of Christianity on Asian Religious Traditions and Cultures}

This second area of interaction is one on which much research and writing has been done. However, we need to re-visit this area to underscore the fact that there are two dimensions to this question. On the one hand, much has been said about the insensitivities of the missionary movement to the religions and cultures they encountered in Asia (Bosch 1996: 293). ${ }^{4}$ Since evangelization, colonization and westernization usually went hand in hand, this dimension of the encounter, based on the imbalances in power relations, has come under much scrutiny and criticism. Of particular concern was that the Christian missionary nervousness about relativism and syncretism led to the creation of Christian communities as alternate communities to the prevalent communities of Asia, thus drawing out and separating the new Christians from their families, cultures and communities (Baustista 2014: 221). ${ }^{5}$ This also meant that Christian missions worked on a 'displacement' model of Theology of Religions, which

4 Bosch (1996: 293) illustrates the pervasive attitude of the missionary movement towards other cultures as follows: "It is certainly not by accident that it is the Christian nations which have become the bearers of culture and leaders of world history' said Gustav Warneck (..) It is the gospel which made the Western nations strong and great; it would be the same for other nations. (..) The effect of the gospel on a nation was to 'soften their manners, purify their social intercourse, and rapidly lead them into the habits of civilized life' (John Abee in 1801)."

5 Julius Baustista in a study of the converted Christians becoming a separate community asserts that apart from the missionary nervousness about relativism and syncretism, the converts themselves saw new opportunities in becoming a separate community. Baustista says (2014: 221), "Conversions were entry points into colonial society, offering with it the opportunity to engage in trade and/or the acquisition of political and military favour. This was not an altogether unreasonable expectation, given that missionaries and colonial administrators drew very definitive geographical boundaries to demarcate the converted from pagans and heathens." 
led not only to exclusivism but also to alienation and even enmity between Christianity and other religious traditions of Asia. What is important to note is that this attitude and approach to other religions were not that of the people that had been converted to Christianity but of those who brought the Christian message to Asia, the mission agencies that sent them, and the theological justifications provided by the Western theological traditions. It displays one of the ways in which 'World Christianity' was conceived during this period, and of the need to reconceive it in our day to deal with the multifaceted dimensions on what it is, what it seeks to explore, and the purpose thereof.

\section{World Christianity and the Bible}

Within this concern, there has been a narrower specialization on the role of Bible in colonialism and how it was interpreted in the colonial context to justify a particular relationship to other religious traditions. Postcolonial studies and interpretations of the Bible throw much light on some of the hidden factors at work in creating the nature of the interfaith relations at that time. R.S. Sugirtharajah, for instance, has written a number of volumes of 'postcolonial explorations' on the use and interpretation of the Bible which is instructive on this question, illustrating the need, within the study of World Christianity, to explore in depth, the way the Bible has been used in preaching and evangelization in the context of other religions, and how exegesis of some of the selected verses and passages from the Bible (like Matt. 28.19 and John 4.16) were used to deny the validity of other religious traditions and to promote exclusivist views towards them. It is significant that the translation and distribution of the New Testaments or one of the gospels was the primary mode of evangelization, both to pass on the gospel message as well as to deny any salvific value of other religious traditions (Sugirtharajah 2005). Further issues like the role of culture, identity, community, and belonging also provide scope for research because they have had ramifications not only in Asia but also in Africa and Latin America.

\section{Positive Impact of the Missionary Movement}

The negative dimensions of the missions during the missionary era have been rehearsed over the past several decades. However it is equally important to recognize the positive impact Christianity made both on Asian religions and especially the social structures that had evolved from them. The point need not 
be laboured here, for the impact of Christian values on the status of women in Asia, the plight of the girl-child, and universal educational opportunities have been well documented. For instance, James Dennis, who wrote three volumes on Christian Missions and Social Progress, summarizes what he sees as the contribution of Christian Missions to the world of other religions in these words: "The missionary movement made a prime contribution to the abolition of slavery; spread better methods of agriculture; established and maintained unnumbered schools; gave medical care to millions; elevated the status of women; created bonds between people of different countries, which war could not sever; trained a significant segment of the leadership of the nations now newly independent." (cited as in Bosch 1996, 294).

As far as India is concerned, the greatest contribution Christianity made was to shake up the centuries old rigid caste system, especially as it relates to those of the lowest strata of the society, who were considered untouchables and ritually impure. Urbanization and impact of Christianity are the two important forces that began to make a dent on the caste system which still lingers on, even within church life, despite the legal provisions against its practice. Yet, providing education, employment, status, and dignity to this social class has been the most enduring contribution Christianity made to India, which also instigated several indigenous reform movements within Hinduism as well (Kopf 1979). ${ }^{6}$

Equally important are the theological initiatives of those who had been marginalized for centuries, like the Dalit in India, the Minjung of Korea and women's liberation movements in all Asian countries, some of which are located within the Hindu, Buddhist and Confucian religions, but draw their primary inspiration from the encounter of Asian religions and cultures with Christianity and the Christian-inspired liberation movements like the ones in Latin America.

The third phase of Christian encounter, as indicated earlier, is that between the churches and the newly independent nations of Asia, and the fourth phase is the contemporary reality, where Christians are encountering emerging fundamentalist and militant forms of religious expressions not faced earlier. Each of these periods has distinctive modes of Christian relationship to other religions that can be fruitfully explored within the field of World Christianity.

6 Among the Hindu reformers influenced by the gospel were Ram Mohan Roy, who published a booklet called "Precepts of Jesus" and Keshab Chandra Sen who spoke of "Oriental Christ". Cf: Kopf 1979. It is also significant that although Gandhi did not set out to reform Hinduism as his primary focus, he was deeply influenced by Jesus' teachings both for his personal life and for the principles on which he led the Indian independence struggle. 
Enrique Dussel of Argentina, who combines philosophy, theology, and especially history into his work, argues that what is needed in Christian theological encounter with other religions is the "epistemological decolonization of theology." He holds that the metropolitan, colonialist, Latino-German theology has been the backbone of Eurocentrism. By presenting a theology that establishes Christianity "as religion par excellence, members of Christendom can deny other beliefs or religions their own claim to universal truth. Election and revelation as responsibility are confused with election and revelation as privilege, as property, as disqualification of other religions' truth" (Dussel 2013: 28). What is of interest is that Dussel holds that "Even the great twentieth-century theologians such as Henri de Lubac, Karl Rahner, Yves Congar or Jürgen Moltmann could not escape their Eurocentrism. They creatively renewed European theologies, but they could not set their subjectivity (or even their physical being) in the 'colonial space', in the world of the colonized other" (Dussel 2013: 28).

Dussel holds that the epistemological decolonization of Eurocentric theology is a fact that began in the second half of the twentieth century but that it will occupy the whole of the twenty-first century because this effort will eventually lead to the need "to redo all theology" (Dussel 2013: 29). What Dussel means by the call to "redo all theology" is that the Eurocentric theology cannot be elaborated, extended or modified to accommodate the theological impulses that arise from Christian encounter with other religions and cultures. He holds that one needs to undo many of the previous presuppositions, lay new foundations, and use different theological methodologies in order to do an adequate theology that takes religious plurality seriously (Ariarajah 2012). ${ }^{7}$ But, is it possible? Is it necessary? How it can be done?

C.S. Song, a veteran of Asian theologies from Taiwan, accused Western theological traditions to be in "Teutonic captivity", and basically went all out to call for the contextualization of all theological reflections in Asia, with the conviction that it is possible to do Christian theology entirely with Asian resources. He attempted to show this in his own volumes (Song 1986). Contextual theology is the most popular, recognizable theology in most Asian and African countries, and many of the theologians, as C.S. Song did, do their theologies in parallel to the dominant Western tradition and not in conversation with it.

However, Sri Lankan theologian, Aloysius Pieris, working in the context of Buddhist-Christian relations, looks at the Christian and Buddhist theological/

7 I have attempted not to 're-do' all theology but to radically 'rethink' all the main doctrines of the church for a religiously plural world. See Ariarajah 2012. 
philosophical traditions as complementary to each other. Recognizing that these traditions have evolved in different social, cultural and philosophical environments, it is no surprise that they, at first sight, appear to be irreconcilable. But Pieris is of the view that each in itself is incomplete and needs the other so that both can have a fuller understanding of 'Truth'. At the heart of Pieris' thesis is the conviction that the Semitic and Asian approaches to reality are not contradictory but complementary to each other. He goes even further to insist that these two idioms are not simply philosophical/ theological but are also psychological realities. He holds that they are "instincts" that arise dialectically from within the deepest zone of each individual irrespective of religious affiliation. Our religious encounter with God and humankind would be incomplete without this interaction.

To quote from his book Love Meets Wisdom, "A genuine Christian experience of God-in-Christ grows by maintaining a dialectical tension between the two poles: Between action and non-action, between word and silence, between control of nature and harmony with nature, between self-affirmation and self-negation, between engagement and withdrawal, between love and knowledge, between karuna and prajna, between agape and gnosis" (Pieris 1998: 27; Pieris 1988).

If there is any truth to Pieris' contention, then there is a significant field of work in World Christianity that goes beyond comparative religion and comparative theology to explore whether the other religious tradition provide resources for a fuller expression of the Christian theology for both East and West. It also means that Christianity and Christian theology should also become accessible to other religions in order to enrich them.

In this context one also needs to listen to the prophetic warning of Wilfred Cantwell Smith that we need to become more aware of the reality that religious traditions are increasingly "becoming strands of the common religious history of humankind" and that being a Christian or a Hindu are no longer such stark alternatives as they used to be. In his view,

All human history is Heilsgeschichte. Not Israel's only, either the old or the new; but the history of every religious community, every human community. This has always been true; although we are the first generation of Christians to see this seriously and corporately, and to be able to respond to the vision. We are the first generation of Christians to discern God's active and splendid and ongoing mission to humankind in the Buddhist movement, in the Hindu, in the Amerind, as well as in the Jewish and the Christian.

quoted as in Cracknell 2001: 200 
In his introduction to the article above, Kenneth Cracknell says that, however cosmic salvation is pictured, Smith is sure that it is the same for all people whatever their religious tradition. "Ask him how he can be so sure of this, Smith replies again: 'I know the empirical dimension from my historical studies (and my friendships); and I know the theological dimension because of what I know of God: by what I find revealed to me of Him in Christ'” (Cracknell 2001: 199).

What Smith suggests is that if we believe God to be the God of the whole creation who cares for the whole creation, we cannot dismiss God's dealings with peoples of other religious traditions and their responses to God with the cultural and philosophical tools available to them. Any religious tradition that seeks to talk about God (do theology), without taking full account of the life others have with God, leaves out too much of the data needed to talk meaningfully about God. He holds that as human community draws closer together, theology must be from, about, and for the whole human community.

It would appear that Pieris and Smith are suggesting a new agenda for World Christianity that needs to move well beyond recognizing and articulating the forms of Christianity and Christian theologies in the world. They suggest that the emerging world community and the mutual knowledge, interactions, and shared life call for a much more inclusive theology than we have imagined so far. Smith's call "towards world theology" may make some nervous and others to see it as premature. My own sense, however, is that Smith is being prophetic and is able to discern not only what is coming, but also what needs to come. The question we face is: What will be the role of the field of World Christianity in tracking, facilitating, and nurturing this development.

World Christianity and Missions

In my own thinking the most underdeveloped field of Christian academic disciplines is missiology. No doubt, there is a long history of missiological thinking which is extensively documented and commented upon; there is no dearth of volumes on mission and missiology from numerous perspectives. They have been studied, for instance, in David Bosch's Transforming Mission. Paradigm Shifts in Theology of Mission (1991). A number of concepts like 'Partners in Mission', 'Churches in Mission', 'Mission in the Six Continents', and 'God's Mission' (Missio Dei) had been conceived over the period of time, to correct, enhance and re-direct mission thinking. Also of significance are studies on mission as it relates to the poor and marginalized, and somewhat unsuccessful but concerted attempts to understand mission in different cultural contexts. 
But despite of the long history of discussions, some of the basic assumptions on mission remain unchanged. The claim that the church has a missionary mandate to 'make disciples of all nations', based on a particular interpretation of the 'Great Commission' in Matthew 28, and the statement attributed to Jesus by John that "no one comes to the Father except through me" (John 14.6) still play, in one way or another, a major role in shaping mission thinking. Only lip service is done to the reality that there are other understandings of what constitutes mission in the Hebrew Scriptures and in other parts of the New Testament. Again, in spite of the considerable advances in the discussions on the Theology of Religions and on interfaith relations and dialogue, the exclusive and inclusive positions are the ones that continue to inspire mission thinking. The latest statement on Mission and Evangelism by the WCC Commission on Mission and Evangelism was brought to the last Assembly of the wCC in Busan, Korea. It is a good and comprehensive statement, moving the focus of mission-thinking on to the Holy Spirit, and incorporates most of the contemporary thinking on mission. Yet, it is within the framework of an inherited understanding of mission (Together towards Life, 2012).

It is important to recognize that mission is not a new idea to Asian religions. Buddhism is perhaps the most successful missionary religion in the world. Although it had its humble origins in North India today most countries in Asia (Tibet, China, Korea, Taiwan, Hong Kong, Sri Lanka, Thailand, Myanmar, and Indochina) have embraced Buddhism, and in many of them it is the majority religion, and it has effectively changed the cultural ethos of the peoples of these nations towards Buddhism. It is significant that although Buddhism had royal patronage in many countries by first taking the Buddhist message to the rulers, it had this enormous success in mission without the help of an empire (Heirman and Bumbacher 2012; Horner 2016).

The success of Buddhism as a missionary religion can be analysed from many angles. I would highlight here three reasons that, in my thinking, contributed to its success. To begin with, Buddhism, like Christianity and Islam, is a founded religion with a founder and his core teaching on the human predicament and the way to overcome it. It is a common practice for founded religions, sometime after the demise of the founder, to gather up the teachings of the founder and to give to them some form of scriptural status. According to tradition the followers of the Buddha also made a concerted attempt to gather together the teaching the Buddha had given on many occasions and places. It is said that a council of monks carefully selected a body of teachings and the monastic disciplines that he had taught (Holm and Bowker 1994: 12-13). In the case of Islam and Christianity the scriptures were gradually given divine status as the words/word of God. Islam, in order to safeguard the original message, 
was uncompromising in insisting that the Qur'an consists teachings directly given by Allah and that it should be followed by whoever embraces Islam, irrespective of their national and cultural location. In the case of Christianity, creeds, doctrines and dogmas were created, and monitored by the teaching authority of the church, to protect the purity of the faith as it moved across cultural boundaries.

In the case of Buddhism, however, when the tradition began to move into other countries and different cultural contexts there was no centralized control of the Buddhist canon or any attempt to lay down doctrines to safeguard the original faith. In the real spirit of Buddhism, it 'let go' of both the Buddha and the scriptures. This resulted in Buddhism adapting and syncretising with the cultures into which it went, resulting in many forms of Buddhism such as Tibetan, Chinese, Sri Lankan, Thai, Vietnamese and so on. Today there are a number of different Buddhist scriptural canons in different languages (loosely based on the basic teachings of the Buddha), and the images of Buddha are distinctly different between Sri Lanka, Tibet and Japan. The Pure Land Buddhism in Japan has moved quite far away from the teachings given by the Buddha in North India. As a result, while Islam and Christianity are treated as 'foreign religions', despite its origins in India, all the Buddhist nations treat Buddhism as their native religion.

The second significant reason is that Buddhism did not attempt to create an alternate religious community nor had initiation ceremonies to mark out the Buddhists from others. Buddhist priests lived a very simple life in the midst of the villagers, entirely depending on the people to sustain them, and simply preached the dharma in return; gradually it 'evangelized' the cultures and the nations instead of gathering individual converts or forcing the religion on the people through colonial power, as Christianity and Islam did in many contexts.

Third, by presenting Buddhism as a 'way of life' that is based on nonviolence, renunciation, and compassion, it was able to win the support of the rulers to propagate its message among their people. Buddhism was never experienced as a 'threat' by the rulers or the people. Although Buddhism is based on a very radical philosophical analysis of the nature of reality and human existence, in practice it presented itself as a way of life that was easy to understand and follow.

A scholarly study of Buddhist expansion would, of course, have to deal with the historical, sociological, political, and cultural factors that contributed to its spread, and the ups and downs it experienced in the course of its expansion. The features mentioned above, however, give the reasons why Asian nations, while embracing Buddhism as their own, feel threatened by Christianity and Islam. 
Although it is not common to associate Hinduism with missions, many missionary movements did originate and established themselves. The most prominent among them are the Ramakrishna Mission, and the Vedantic Centres both in India and all parts of the world. Even as Christianity grew out of Judaism, Buddhism, Jainism and Sikhism grew out of Hinduism, attracted followers and established themselves as separate religious traditions as did Christianity. Missions, therefore, is not new to Asian religious traditions, and no doubt, some tensions, conflicts, and periods of persecution did appear when new religions came out of Hinduism. Yet, they soon settled down as sister religious traditions. In spite of this missionary heritage of their own, today Christianity and Islam are being accused, rightly so, as religions traditions that do not respect the concept of mission in Asian religions and cultures. What are the reasons for growing resentments against Christian and Muslim missions?

While Christianity and Islam, for the most part, work on a displacement model, creating alternate communities, Asian traditions have followed some basic principles on mission that have served them well in holding together religiously diverse nations. I would summarize here four of the principles of mission in Asian religions that Christianity needs to take note of. First, all missions in the Asian religious traditions happen within the basic principle of respect for plurality. Although this principle is violated in counties like India, Sri Lanka and Myanmar, where religion is turned into a political ideology or is abused for political purposes, a majority of the adherents of these traditions would themselves reject any intolerance of plurality which is enmeshed into Asian religious thought. While claims are made to the salvific value of a message, there is reluctance in Asia to claim that it is the 'only way', or to say that other ways of being and believing would lead to damnation.

Second, while some organized missions do take place, there is no sense of 'urgency' and there is no anxiety to 'win' converts to the faith. In Asian mission understanding while one has the privilege of sharing the message, the burden of responding or not responding to the message is placed on the hearers. The anxiety on the part of the messenger that there should be an overt and positive response to his or her mission is viewed with suspicion.

Third, Asian religious traditions are reluctant to engage in mission on the authority of scriptures. While the scriptures are important for spiritual growth and nourishment, the desire to share the message should come entirely out of one's own inner spiritual authority that comes out of an intensity of spiritual experience.

Last, missions, even when they promote different spiritual orientations, should not lead to alienation of the people from their cultural moorings and 
the sense of belonging to the larger community. Missions that disrupt community are viewed with deep suspicion.

My own sense has been that while Christians have indigenized to varying degrees Christian theology, worship, art, architecture, and music, they have not truly indigenized their understanding and practice of mission, and are increasingly paying a heavy price for it. This is also the reason why I am not as excited with the growth of Christianity in the South as some others, because often the missions that are said to succeed today follow the 18th and 19th Century missionary practices, based on missiology of that time that has once been tried and found wanting. After all the missionary efforts put into India, for instance, with educational, social, health-care institutions, the colonial power that was behind them, and the thousands of missionaries that have given their lives in mission work, not even three percent of India has become Christians in the form that was intended - the creation of alternate Christian communities. As seen earlier, the gospel message did make a great impact and it has brought many forms of liberation to sectors within the Asian societies, but institutional dimension of the missionary enterprise has little to show in return for the efforts it had put in over the centuries.

This is an important issue for the discipline of World Christianity because mission has always been considered 'world mission'. Somewhere in the middle of mission discussions the concepts of 'mission in the six continents' and 'partners in mission' emerged, which by implication indicated that both missiology and mission practices are the burdens of the global Christian community. The emergence of new answers to such questions as: 'what is mission?', 'why are we in mission, who are the partners in mission, what we hope to achieve by mission?', and 'when is mission accomplished?' need to come from within the field of World Christianity. These are questions that baffle Christians both in the North and the South and answers to these questions will make lasting impact on Christian relationship to peoples of other religious traditions. Postcolonial theology can take us only to some distance; it is only a postcolonial missiology that would take us rest of the way in a world which, in the words of Wilfred Cantwell Smith, has gone "irreversibly interfaith."

\section{9}

\section{Wider Ecumenism}

Two other developments within Christianity have implications for Christian relationship to other religious traditions that transcend geographical boundaries. The first is a gradual, but increasing call, to reconsider what 
should constitute ecumenism. Traditionally ecumenism was understood as a movement that seeks to serve the search for unity among Christians in faith, mission, and service to the world. However, with the growth in interfaith dialogue, and cooperation among religious traditions in meeting the growing challenges facing the global community, pressures are mounting to rethink what constitutes 'ecumenism'. The Greek word oikoumene from which ecumenism arose simply denotes the 'whole inhabited earth'. Although the word was appropriated already from the time of the early Ecumenical Councils of the church to serve the cause of Christian unity, today the word may have to be revitalized to denote the search of the unity of the whole human community, which includes the religious traditions. There is a sense in which such international interfaith organizations as the Parliament of the World's Religions and Religions for Peace are expressions of a new or wider ecumenism.

I had said the following in an article written earlier on the need for a wider ecumenism, especially for those who live among other religious traditions:

At the global level, there is increasing recognition that the world's problems are not Christian problems requiring Christian answers, but human problems that must be addressed together by all human beings. We know today that whether it is the issue of justice, peace, human rights or the destruction of the environment, we need to work across boundaries of religions, nations and cultures.... So the question "how ecumenical 'ecumenical' should be" is no longer a question of semantics or inclusion; it is a theological question. It has to do with a reassessment of our understanding of God, of the scope of God's saving work, and of the agents of God's mission.

Ariarajah 1998: 327

I have also argued that this is a particular problem for those Christians who live as minorities in multi-faith societies:

Those Christians who live in contexts where the society is made up mainly of people who profess other faiths or live by other ideologies, and whose life and death issues are intimately related to their neighbours, refuse to believe that God's reconciliation and redeeming work in these societies is put on hold until the churches are able to overcome divisions that are part of another age and culture. (...) The call for "wider ecumenism", therefore, is a call to discernment. It is an attempt to make more 
sense than before of the conviction we hold that the Spirit of God is active in the world. It is an attempt to give more meaning than before to our belief that "The earth is the Lord's and the fullness thereof, the world and those who dwell in it." (Ps. 24:1)

Ariarajah 1998: $327-328$

What such a new ecumenism needs to look like, what is the nature of the relationship between the Christian ecumenism and the wider ecumenism, and how one could promote internal ecumenism within the factions and branches within other religious traditions are all questions that can fruitfully engage World Christianity.

The other area that is emerging within Christian presence in religiously plural societies is the concept of public theology. The field itself is not new, and it had grown out of the felt need to interact with public issues that arise within society that affect all communities irrespective of religion, culture or ethnicity. The need for this field was also precipitated by the forces of globalization which presented issues that were challenges to all faith communities. Since all public issues are multi-faceted, public theology needs to be multi-disciplinary to engage in dialogue with different academic disciplines such as politics, economics, cultural studies, and religious studies. There is today a global network of public theology and a journal associated with it: The International Journal of Public Theology. One of the proponents of public theology in India, especially in the context of Hinduism, is Felix Wilfred, who had done much to clarify it and to show the parameters of reflection that is called for (Wilfred 2014b: 558-574).

He makes two importance emphases. The first is that public theology should be of service to the concerns of the poor and marginalized masses of Asia. Second, that this theology, although arising out of Christian convictions, needs to be open to the participation of peoples of other religious traditions and ideologies who would bring in their own resources to the task. This means public theology will not be theology done only to open up and enliven Christian interest and meaningful participation in public issues, but also one that is done with peoples of other religious traditions and ideologies in the interest of the common good of the whole community. Here interfaith relationship is raised to a new level of engagement that may help to bring religious communities closer together than other forms of dialogue. 
Faced with the problems raised by the more assertive entry of religions into the public space and having to deal with religious extremism, militant forms of religious expressions, and fundamentalist interpretations of religions, public theology is not only a local or national concern but one that needs explorations at the global level. World Christianity thus is entering a phase where, beyond statistics and demographic studies, it needs to become a space where contemporary issues raised by the interfaith realities are addressed from multi-disciplinary perspectives. Here is a challenge and an agenda for World Christianity that needs to be further examined and implemented.

\section{Future of the Discipline}

The foregoing consideration may appear to be placing many more burdens and unrealistic expectations on the emerging field of World Christianity. The intention here, however, is to open up the many avenues that can and needs to come under its purview if it is to carry the full import of the word 'world' in its name. Mapping the demographic changes and its consequences to our understanding and practice of mission is only part of this task. Greater challenge is to study the theological consequences of these changes, even as Christians in non-Western parts of the world call for the decolonization of theology, make their own input, and seek to discover those things that can still hold the global Christian community together as part of the one body of Christ. This task is further complicated as Christians living as minorities in religiously plural societies seek both to make theological sense of other ways of believing and being and attempt to take religious plurality seriously in their own theological task.

We have also seen that the closer relationship between religious traditions challenges the narrow understanding of ecumenism as the search for unity of the churches in faith, witness and service. Christians in all parts of the world are being challenged to find ways of seeking the unity of human communityunderstood as a call for a Wider Ecumenism. Related to it is the increasing voices from both the East and the West that discern the need to place all theological thought at the service of the world, in order to find values and principles of living together in justice and peace. Even as religions enter the public space from many different perspectives and for different purposes, there is also the call for a robust discipline of 'public theology' that draws from all what religions and secular movements have to offer towards finding, advocating, and practicing life-centred values to govern our common public life. In other words, the discipline of World Christianity is being challenged to become the forum, the space, the stage and the locus to advocate, facilitate and foster the 
emergence of Christianity as a religion that is responsive to diversity, inclusivity and plurality.

\section{Bibliography}

Ariarajah, S. Wesley (1991). Hindus and Christians. A Century of Protestant Ecumenical Thought. Amsterdam: Rodopi \& Grand Rapids, Michigan: William B. Eerdmans.

Ariarajah, S. Wesley (1998). 'Wider Ecumenism. A Promise or a Threat?' The Ecumenical Review 50,3: 321-329.

Ariarajah, S. Wesley (2012). Your God, My God, Our God. Rethinking Christian Theology for Religious Plurality. Geneva: wcc Publications.

Baustista, Julius (2014). 'Colonialism, Nationalism and the Caveats to Conversion.' In Felix Wilfred, ed. (2015). The Oxford Handbook of Christianity in Asia. New York: Oxford University Press: 215-230.

Bosch, David J. (1996 [1991]). Transforming Mission. Paradigm Shifts in Theology of Mission. Maryknoll, N.Y: Orbis.

Commission on the Missionary Message. Hinduism II. Bound manuscripts (catalogue number 280.215w893c). wCC Library: 92-107.

Cracknell, Kenneth (1995). Justice, Courtesy and Love. Theologians and Missionaries Encountering World Religions, 1846-1914. London: Epworth Press.

Cracknell, Kenneth, ed. (2001). William Cantwell Smith. A Reader. Oxford: Oneworld Publications.

Dussel, Enrique (2013). 'The Epistemological Decolonization of Theology.' Concilium 2013,2: 21-31.

England, John C. (1996). The Hidden History of Christianity in India. The Churches of the East before 1500. Delhi: ISPCK \& Hong Kong; CCA.

Gallagher, Robert L. and Paul Hertog, eds (2009). Landmark Essays in Mission and World Christianity. Maryknoll NY: Orbis Books.

Heirman, Ann and Stephen P. Bumbacher, eds (2012) The Spread of Buddhism. Leiden: Brill.

Holm, Jean and John W. Bowker (1994). Sacred Writings. London: Printer Publisher Ltd. Horner, Jeremy (2016). Nirvana. The Spread of Buddhism Through Asia. Leiden: Brill.

Kopf, David (1979). The Brahmo Samaj and the Shaping of the Modern Indian Mind. Princeton: Princeton University Press.

Moffett, Samuel H. (1998). A History of Christianity in Asia. Vol. I: Beginnings to 1500. Maryknoll NY: Orbis.

Moffett, Samuel H. (2005). A History of Christianity in Asia. Vol. 2: 1500-1900. Maryknoll NY: Orbis. 
Podipara, Placid (1973). 'Hindu in Culture, Christian in Religion, Oriental in Worship.' In George Menachery, ed. St. Thomas Christian Encyclopedia of India, Trichur, India: STCEI, vol. 2: 107-112.

Rae, G. Milne (2012). The Syrian Church in India. London: Forgotten Books.

Pieris, Aloysius (1988). Asian Theology of Liberation, Maryknoll NY: Orbis Books.

Pieris, Aloysius (1998). Love Meets Wisdom, Maryknoll NY: Orbis Books.

Sine, Nomine (2017). "Frontmatter." The Journal of World Christianity 7,1: no page numbers.

Song, Choan S. (1986). Theology from the Womb of Asia, Maryknoll NY: Orbis Books.

Stanley, Brian (2009). The World Missionary Conference, Edinburgh 1910. Grand Rapids, Eerdmans.

Sugirtharajah, Rasiah J. (2005). The Bible and Empire. Postcolonial Explorations. Cambridge: Cambridge University Press.

Tan, Jonathan Y. and Ahn Q. Tran, eds (2016). World Christianity. Perspectives and Insights. Essays in Honor of Peter C. Phan. Maryknoll NY: Orbis Books.

Tennent, Timothy C. (2007). Theology in the Context of World Christianity. How the Global Church is Influencing the Way We Think about and Discuss Theology. Grand Rapids: Zondervan.

'Together towards Life. Mission and Evangelism in Changing Landscapes.' (2012) WCC Resources. http://www.oecumene.nl/files/Documenten/Together_towards_life.pdf, accessed November 152017.

Wilfred, Felix, ed. (2014a). The Oxford Handbook of Christianity in Asia, New York: Oxford University Press.

Wilfred, Felix (2014b). 'Asian Christianity and Public Life. The Interplay.' in Felix Wilfred, ed., The Oxford Handbook of Christianity in Asia. Oxford: Oxford University Press: $55^{8-574 .}$

Winkler, Dietmar, ed. (2013). Syriac Christianity in the Middle-East and India. Contributions and Challenges. Piscataway, NJ: Gorgias Press.

World Missionary Conference 1910, Report of Commission IV (1910). Edinburgh/London: Oliphant, Anderson, and Ferrier. 